\title{
PENDUGAAN DAYA PRODUKSI SUSU DAN BEBERAPA NILAI PARAMETER GENETIK PADA SAPI PERAH FRIES HOLLAND
}

\author{
Neli Definiati dan Sartini \\ Fakultas Pertanian Universitas Muhammadiyah Bengkulu.
}

\begin{abstract}
The aims of the present research were to calculate some genetically parameters for estimation of milk production potency of dairy cattle based on the recorded data for 10 years of production. Parameter calculated included: heredity, repeatability and production capacity. The data was collected from PT. Taurus Dairy Farm Sukabumi during the period of 1990-2000. Heredity and repeatability values were determined by variance and covariance analysis based on paternal half in completely randomized design. Calculation of milk production capacity was based on most probable producing ability (MPPA) formula. Results showed that the highest milk production of about $3.565 .71 \pm 670.021 \mathrm{~kg} / \mathrm{y}$ was obtained during the first lactation period and followed by the fourth lactation period of $3.331,80$ $\pm 806,35 \mathrm{~kg} / \mathrm{y}$. The highest heredity value of $0,36 \pm 0,35$ was obtained at first lactation, followed by third lactation of $0,25 \pm 0,31$, fourth lactation $0,22 \pm 0,30$. The repeatability value of milk production was found 0,33 .
\end{abstract}

Key words: heredity, repeatability, dairy cattle.

\section{Pendahuluan}

Produksi susu ditentukan oleh faktor lingkungan dan faktor genetik. Usaha peningkatan produksi susu harus memperhatikan mutu genetik ternak disamping pengendalian kondisi lingkungan yang ideal bagi sapi perah, sehingga dengan mutu genetik tinggi pada kondisi lingkungan yang optimal diharapkan dapat memberikan produksi yang maksimal.

Sebagai langkah awal dalam perbaikan genetik ternak adalah pencatatan (recording) dari masing-masing ternak, sehingga dari recording tersebut dapat dengan mudah mengetahui silsilah (keturunan) produksi ternak yang sangat diperlukan dalam meramalkan nilai genetik sebagai dasar dari program pemuliaan ternak.
Program seleksi pada sapi perah betina merupakan salah satu upaya yang dilakukan untuk meningkatkan produktifitas sapi perah melalui evaluasi mutu genetik ternak. Untuk mengetahui mutu genetik sapi perah diperlukan parameter genetik seperti heritabilitas $\left(\mathrm{h}^{2}\right)$ dan ripitabilitas $(\mathrm{r})$, sehingga dari kedua nilai genetik ini dapat dipergunakan untuk meramalkan kemampuan produksi susu (Most Probable Producing Ability) dari sapi perah, karena daya produksi susu merupakan taksiran mendekati kemampuan susu yang riil.

Pengurutan sapi perah berdasarkan daya produksi susunya sangat bermanfaat dan efektif untuk menentukan pilihan sapi perah yang terus diternakan dan dijadikan bibit serta harus dikeluarkan dari perusa- 
haan (Mc. Dowell, 1972, Campbell dan Marshall, 1975).

Beberapa parameter genetik seperti heritabilitas, merupakan tolok ukur dalam program seleksi dan dapat menentukan arahan terhadap hasil seleksi. Heritabilitas merupakan kekuatan suatu sifat yang diturunkan dari tetua kepada anaknya. Pendugaan nilai heritabilitas merupakan perbandingan antara ragam genetik dan ragam fenotifik. Kegunaan dari pendugaan nilai heritabilitas adalah untuk menunjukkan laju perubahan yang dapat dicapai dari seleksi dari sifat tersebut di dalam populasi. Heritabilitas merupakan parameter yang digunakan untuk pendugaan nilai pemuliaan pada sifat kuantitatif dan untuk menduga respon yang diharapkan dari berbagai seleksi yang akan dilakukan (Van Vlecket et al, 1986). Pada akhirnya, nilai heritabilitas akan memberikan keuntungan bila ditinjau dari segi ekonomi (Lush, 1969), karena seleksi terhadap sifat yang mempunyai nilai heritabilitas rendah relatif kurang efektif dibandingkan dengan seleksi terhadap sifat yang mempunyai nilai heritabilitas yang tinggi.

\section{Materi dan Metode}

\section{Tempat dan Waktu Penelitian}

Penelitian ini dilaksanakan di perusahaan peternakan PT. Taurus Dairy Farm. Alasan pemilihan lokasi ini karena PT. Taurus Dairy Farm telah mempunyai catatan/recording yang cukup lengkap sebagai dasar dari penelitian ini dan mudah dijangkau. Bahan penelitian adalah catatan produksi susu sapi perah Fries Holland pada laktasi pertama sampai dengan laktasi ke empat.
Penelitian dilakukan selama 5 bulan mulai dari bulan Januari 2003 sampai dengan bulan Juni 2003.

\section{Metode yang Digunakan}

Metode yang digunakan adalah studi kasus dan teknik pengambilan data dilakukan dengan metode purposive sampling. Data yang diambil adalah data produksi susu sapi bulanan dari laktasi pertama sampai dengan laktasi keempat yang mempunyai kelengkapan catatan produksi. Kelengkapan catatan produksi tersebut diantaranya catatan lama laktasi, nomor induk, nama pejantan, tanggal dan tahun kelahiran serta tahun sapi tersebut pertama berproduksi dan terakhir berproduksi. Selain data tersebut diambil data lainnya sebagai data pelengkap yang erat kaitannya dengan penelitian ini, seperti jumlah dan jenis pakan yang diberikan serta manajemen pemeliharaan di perusahaan tersebut.

Sebelum dilakukan analisis statistik, data yang diambil terlebih dahulu distandarisasikan pada 305 hari pemerahan, umur setara dan dua kali pemerahan berdasarkan faktor koreksi dari tabel Rice et al (1978).

\section{Analisis Statistik}

\section{(1). Analisis Pendugaan Nilai Heritabilitas}

$$
\text { Heritabilitas }=\frac{4 \sigma^{2} s}{\sigma^{2} s+\sigma^{2} w}
$$
(2). Analisis Untuk Menduga Nilai Ripitabilitas

Untuk menduga nilai ripitabilitas berdasarkan metode korelasi dalam kelas menurut petunjuk Becker (1975) sebagai berikut: 


$$
\text { Ripitabilitas }=\frac{\sigma^{2} \mathrm{w}}{\sigma^{2} \mathrm{w}+\sigma^{2} \mathrm{E}}
$$

Keterangan :

$$
\begin{aligned}
\sigma^{2} \mathrm{~W}= & \text { komponen ragam antar } \\
& \text { individu } \\
\sigma^{2} \mathrm{~s}= & \begin{array}{l}
\text { komponen ragam peng- } \\
\text { ukuran dalam individu }
\end{array}
\end{aligned}
$$

\section{(3). Analisis Daya Produksi Susu}

Untuk menduga daya produksi susu sapi perah pada penelitian ini digunakan menurut petunjuk Warwick et al (1995) dan Harjo- subroto (1994), dengan rumus sebagai berikut :

$\mathrm{nr}$

$$
\mathrm{MPPA}=\frac{}{1+(\mathrm{n}-\mathrm{r}) \mathrm{r}}(\bar{p}-\bar{p})+\bar{p}
$$

Keterangan :

MPPA $=$ Most Probable Producing Ability ( daya produksi susu)

$\mathrm{n} \quad=$ Jumlah pengamatan

$\mathrm{r}=$ Angka pengulangan

$\bar{p} \quad=$ Rata-rata produksi susu individu

$\bar{p} \quad=$ Rata-rata produksi populasi

Tabel 1. Analisis Ragam untuk Menduga Nilai Heritabilitas Produksi Susu Laktasi Pertama, Kedua, Ketiga dan Keempat.

\begin{tabular}{|l|l|c|c|c|}
\hline $\begin{array}{c}\text { Sumber } \\
\text { Keragaman }\end{array}$ & $\mathrm{Db}$ & $\begin{array}{c}\text { Jumlah } \\
\text { Kuadrat }\end{array}$ & Kuadrat Tengah & $\begin{array}{c}\text { Komponen } \\
\text { Pendugaan }\end{array}$ \\
\hline Antar Pejantan & $\mathrm{S}-1$ & $\mathrm{JKs}$ & $\mathrm{KTs}$ & $\sigma^{2} \mathrm{w}+\mathrm{k} \mathrm{\sigma ^{2 } \mathrm { s }}$ \\
\hline $\begin{array}{l}\text { Anak dalam } \\
\text { pejantan }\end{array}$ & $\mathrm{S}(\mathrm{n}-1)$ & $\mathrm{JKw}$ & $\mathrm{KTw}$ & $\sigma^{2} \mathrm{w}$ \\
\hline Keterangan : $\quad \mathrm{S}$ & $=$ Jumlah pejantan \\
$\mathrm{N} \quad$ & $=$ Jumlah anak tiap pejantan \\
$\sigma^{2} \mathrm{w}$ & $=$ Pendugaan komponen ragam anatar anak dalam pejantan \\
$\sigma^{2} \mathrm{~s}$ & $=$ Pendugaan komponen ragam pejantan \\
$\sigma^{2} \mathrm{w}$ & $=$ KTw
\end{tabular}

Tabel 2. Analisis Ragam untuk Menghitung Ripitabilitas Produksi Susu Sapi Perah Fries Holland.

\begin{tabular}{|c|c|c|c|c|}
\hline $\begin{array}{c}\text { Sumber } \\
\text { Keragam }\end{array}$ & $\mathrm{Db}$ & $\mathrm{JK}$ & $\mathrm{KT}$ & $\begin{array}{c}\text { Pendugaan } \\
\text { Komponen }\end{array}$ \\
\hline Antar individu & $\mathrm{n}-1$ & $\mathrm{JKw}$ & $\mathrm{KTw}$ & $\sigma_{\mathrm{E}}^{2}+\mathrm{k} \sigma^{2} \mathrm{w}$ \\
\hline $\begin{array}{c}\text { Pengukuran } \\
\text { dalam individu }\end{array}$ & $\mathrm{n}(\mathrm{n}-1)$ & $\mathrm{JK}_{\mathrm{E}}$ & $\mathrm{KT}_{\mathrm{E}}$ & $\sigma_{\mathrm{E}}^{2}$ \\
\hline
\end{tabular}


Tabel 3. Rata-rata Produksi Susu Laktasi Pertama, Kedua, Ketiga dan Keempat dan Daya Produksi Susu

\begin{tabular}{|c|c|c|}
\hline Periode Laktasi & Produksi Susu (liter) & Koefisien Variasi (\%) \\
\hline I & $3565,70 \pm 670,09$ & 18,76 \\
\hline II & $3211,81 \pm 736,49$ & 22,93 \\
\hline III & $3208,65 \pm 737,37$ & 22,98 \\
\hline IV & $3331,80 \pm 806,53$ & 24,21 \\
\hline Rata-rata & $3329,49 \pm 750,28$ & 22,53 \\
\hline Daya Produksi & $3329,49 \pm 337,21$ & 10,13 \\
\hline
\end{tabular}

\section{Hasil dan Pembahasan}

\section{Produksi Susu Perlaktasi dan Daya Produksi}

Hasil analisa terhadap produksi susu dan daya produksi pada penelitian ini dapat dilihat pada Tabel 3. Memperhatikan Tabel 3 di atas, laktasi pertama menunjukkan produksi susu tertinggi (3 565,70 \pm 670,09 liter) diikuti laktasi keempat (3 331,80 $\pm 806,53$ ), laktasi kedua (3 $211.81 \pm 736.49)$ dan terendah diperoleh pada laktasi ke tiga (3 208,65 \pm 737,37).

Penurunan produksi susu pada penelitian ini disebabkan juga oleh faktor lingkungan yang bersifat sementara seperti tatalaksana pemberian makanan pada sapi-sapi yang telah dua atau lebih berlaktasi tidak sesuai dengan kebutuhan sapi tersebut untuk berproduksi optimal, karena jumlah makanan yang diberikan tidak berbeda sehingga penurunan produksi terjadi pada saat itu.

\section{Ripitabilitas}

Nilai ripitabilitas produksi susu yang diperoleh pada penelitian ini adalah sebesar 0,33. Nilai ini merupakan komponen yang penting dalam memperkirakan daya poduksi susu sapi perah. Dengan didapatnya nilai ripitabilitas sebesar 0,33 berarti kemampuan sapi perah di perusahan peternakan ini untuk mengulangi sifat produksinya adalah sebesar 33 persen dipengaruhi oleh faktor genetik dan 67 persen ditentukan oleh faktor lingkungan yang bersifat permanen.

Nilai ripitabilitas yang diperoleh dalam penelitian ini jika dibandingan dengan yang dilaporkan Warwick et al (1995) yaitu sebesar 0,40 - 0,60; Lasley (1978) sebesar 0,41 - 0,64, serta Lee dan Handerson (1972) sebesar 0,35 - 0,50, maka hasil yang diperoleh lebih rendah. Demikian pula jika dibandingkan dengan hasil penelitian di beberapa daerah di Indonesia seperti yang dilaporkan oleh Makin (1983) yang berkisar antara 0,30 - 0,49; Mekir (1982) sebesar 0,45 dan Rumawas (1971) sebesar 0,60. 
Tabel 4. Nilai Heritabilitas dan Galat Baku Produksi Susu Laktasi Pertama, Kedua, Ketiga dan Keempat.

\begin{tabular}{|c|c|c|}
\hline Periode Laktasi & Heritabilitas & Galat Baku \\
\hline I & 0,36 & 0,35 \\
\hline II & 0,15 & 0,28 \\
\hline III & 0,25 & 0,31 \\
\hline IV & 0,22 & 0,30 \\
\hline
\end{tabular}

\section{Heritabilitas Produksi Susu}

Produksi susu merupakan sifat kuantitatif yang efektif untuk diseleksi karena mempunyai nilai heritabilitas cukup tinggi. Analisis nilai heritabilitas produksi susu dari laktasi pertama sampai dengan laktasi keempat pada penelitian ini dapat dilihat pada Tabel 4.

Memperhatikan Tabel 4 di atas, tampak bahwa nilai heritabilitas tertinggi diperoleh pada laktasi pertama $(0,36 \pm 0,35)$ diikuti laktasi ketiga $(0,25 \pm 0,31)$, laktasi keempat $(0,22 \pm 0,30)$ dan yang terendah adalah laktasi kedua $(0,15 \pm 0,28)$. Bila ditelaah maka nilai heritabilitas antar laktasi menunjukkan perbedaan, keadaan ini sesuai dengan pendapat Butcher dan Freeman (1968) bahwa nilai heritabilitas produksi susu laktasi pertama akan berbeda dengan nilai heritabilitas produksi susu laktasi berikutnya.

\section{Kesimpulan}

Dari hasil analisis data pada penelitian ini dapat disimpulkan bahwa:

1. Rataan produksi susu untuk laktasi pertama, kedua, ketiga dan keempat masing-masing adalah sebesar $3565,70 \pm 670,09$; $3211,81 \pm 736,49 ; 3208,65 \pm$ 737,37 dan $3331,80 \pm 806,53$.
2. Rata-rata produksi susu yang diperoleh adalah sebesar 3329,49 $\pm 337,21$ liter dengan nilai ripitabilitas sebesar 0,33. Nilai ini dapat dipergunakan sebagai patokan untuk memilih sapi-sapi perah yang berdaya produksi susu di atas rata-rata dengan harapan produksi susu sapi perah yang diternakkan akan meningkat dan ketepatan seleksi akan lebih baik.

3. Pendugaan nilai heritabilitas pada laktasi pertama, kedua, ketiga dan keempat masing-masing adalah 0,$36 ; 0,15 ; 0,25$ dan 0,22 .

\section{Saran}

Perlu dilakukan penelitian lebih lanjut mengenai pendugaan daya produksi susu pada perah Fries Holland dengan menggunakan lebih banyak catatan produksi susu sehingga nilai rata-rata produksi susu lebih mencerminkan daya produksi susu sapi perah tersebut dan pada gilirannya ketepatan seleksi akan lebih baik.

\section{Daftar Pustaka}

Allaire, F.R. and C.R. Handerson. 1966. Selected Practiced Among Dairy Cows. J. Dairy Sci. 48 : 1426-1434. 
Anggorodi, R. 1979. Ilmu Bahan Makanan Ternak Umum. PT. Gramedia Jakarta.

Banerjee, G.C. 1980. A Text Book of Animal Husbandry. $3^{\text {rd }}$ Edition. Oxford and IBH Publishing Co. New Delhi. Bombay Calcutta.

Barret, B.AAA. and Larkin, P.J. 1979. Milk and Beef Production in the Tropics. Oxford University Press.

Bath, D.L., F.N. Dickinson, H.A. Tucker and R.D. Appleman. 1978. Dairy Cattle Principles, Practices, Problems and Profits. Second Ed. Lea \& Febiger. Philadelphia. P 134; 362-366.

Becker,W.A 1975. Manual of Quantitative Genetics. Second Ed. Washington State University Press. P. 23 - 118, 147 152.

Butcher, D.F. and A.E. Freeman. 1968. Heritabilities and Repeatabilities of Milk and Milk Production by Lactation. J. Dairy Sci. 51 : 1387-1391.

Castle, M.E and P. Watkins. 1984. Modern Milk Production. Second Ed. Faberand Faber. London. P 30,35.

Dinas Peternakan Propinsi Dati I Jawa Barat. (2000). Statistik
Peternakan. Dinas Peternakan Propinsi Dati I Jawa Barat. Bandung.

Esminger, M.E. 1980. Dairy Cattle Science. The Interstate Second Edition. Printers and Publisher, Inc. Danville, Illinois,. P 515$561,590$.

Falconer, D.S. 1981. Introduction to Quantitative Genetics2 nd. Edition. Longman. London. P 312-526.

Gill, J.L. and E.L. Jensen. 1968. Probable of Obtaining Negative Estimatet of Heritability. Biometric 24 : 517-526.

Harjosubroto, W. 1994. Aplikasi Pemulaiaan Ternak di Lapangan Grasindo. Jakarta.

Holmes,C.W. and G.F. Willson. 1984. Milk Production from Pasture. Butterworth Agricultural Books.

Johansson, I. 1961. Genetic aspects of Dairy Cattle Breeding. University of Illinois Press. Urbana, Illinois, p.271, 277.

Kurnianto, E. 1991. Penilaian Pejantan Sapi Perah Berdasarkan Catatan Produksi Susu Laktasi Sebagian. Thesis Fakultas Peternakan IPB.

Alamat korespondensi: Neli Definiati

Fakultas Pertanian Universitas Muhammadiyah

Bengkulu

Diterima: 12 April 2004, Disetujui: 18 Januari 2006 